\section{Australian Journal of \\ Crop Science}

\title{
Non-destructive analysis of photosynthetic pigments in Avena strigosa and Avena sativa
}

\author{
Tiago Edu Kaspary* ${ }^{1}$, Luan Cutti ${ }^{2}$, Cristiano Bellé ${ }^{3}$, Gabriele Casarotto ${ }^{2}$, Mártin Zanchett Groth ${ }^{4}$, Gerarda \\ Beatriz Pinto Da Silva, Adalin Cezar Moraes De Aguiar ${ }^{5}$
}

'Instituto Nacional de Investigación Agropecuaria -INIA La Estanzuela - Ruta 50, Km. 11; 70000, Colonia, Uruguay ${ }^{2}$ Universidade Federal do Rio Grande do Sul, Programa de Pós-Graduação em Fitotecnia, 91540-000 Porto Alegre, Rio Grande do Sul, Brazil

${ }^{3}$ Universidade Federal de Santa Maria, Centro de Ciências Rurais, Departamento de Solos, 97105-900, Santa Maria, Rio Grande do Sul, Brazil

${ }^{4}$ Universidade Federal de Pelotas, Pós-Graduação em Ciência e Tecnologia de Sementes. Campus Capão do Leão s/n, 96001-970 Pelotas, Rio Grande do Sul, Brazil

${ }^{5}$ Universidade Federal de Viçosa, Programa de Pós-Graduação em Fitotecnia, Campus Universitário, 36570 900, Viçosa, Minas Gerais, Brazil

\begin{abstract}
Chlorophylls and carotenoids are the main photosynthetic pigments in plants. The photosynthetic potential of crop plants is used to determine the correct rate of nitrogen fertilization. To date, no studies have been conducted to understand the relationship between different methods of measurement of photosynthetic pigments in oats. The objective of this study was to quantify and compare the levels of photosynthetic pigments in Avena strigosa and A. sativa using two different methods, the extraction method and portable chlorophyll meter, and to determine whether the results of these two methods showed a significant correlation. Photosynthetic pigments were measured using both methods in a greenhouse and the laboratory at four developmental stages: tillering [28 days after sowing (DAS)], vegetative stage I (55 DAS), vegetative stage II (75 DAS), and reproductive stage (120 DAS). The same leaves were used to measure the relative chlorophyll content using a portable chlorophyll meter and extractable chlorophyll using the laboratory extraction method. The readings of the chlorophyll index differed for each developmental stage of both $A$. sativa and A. strigosa. The contents of chlorophyll a, chlorophyll b, and carotenoids determined using the extraction method showed high coefficients of correlation with the total chlorophyll index determined using the portable chlorophyll meter. Thus, the measurement of chlorophyll using the portable chlorophyll meter can be used for the accurate evaluation of the photosynthetic potential of oats, thus saving time and reagents.
\end{abstract}

Keywords: Avena sativa, Avena strigosa Schreb, Carotenoids, Chlorophyll, Portable chlorophyll.

Abbreviations: DAS_days after sowing, DMS_difference minimum significant, DMSO_dimethyl sulfoxide.

Introduction

Avena strigosa Schreb and Avena sativa are multipurpose cereals that are considered important cultivation alternatives for the winter period in southern Brazil. Both of these species are the main forage crops used in the formation of winter pastures, either in isolation or intercropping with other temperate climate species, owing to their high dry biomass and forage quality, trampling resistance, and low production costs (Macari et al., 2006). Both crop species, especially $A$. sativa, are also used as soil cover crops in the no-till system for the production of grains, which are high in proteins, vitamins, minerals, and fiber and are also used as human nutrition (Silva and Ciocca, 2005).

The production potential, mass accumulation, and grain yield of $A$. strigosa and $A$. sativa are related to their competitive capacity, speed of establishment, and use of environmental resources. Thus, the photosynthetic potential of these crop species and higher levels of leaf pigments are linked to high rates of accumulation of photoassimilates as well as the rapid establishment and development of plants in different environments (Engel \& Poggiani, 1991; Fleet et al., 2003). The photosynthetic efficiency of crop plants is used to determine the rate of nitrogen fertilization because the total chlorophyll content is associated with the organic nitrogen content of leaves and consequently crop yield in many cultures (Smeal \& Zhang, 1994; Rigon et al., 2012; De Castro et al., 2014).

The levels of photosynthetic pigments are measured mostly using traditional methodology, which comprises the destruction of leaf samples. Moreover, it is a costly procedure as it involves the use of laboratory reagents, thus making it impractical because it does not produce instant results. In contrast, portable chlorophyll meters use nondestructive, simple and instantaneous principles (Salla et al., 2007). In recent years, portable chlorophyll meters have been successfully used to measure the levels of photosynthetic pigments and leaf nitrogen content in different species (Ciganda et al., 2009; Rigon et al., 2012; 
Rigon et al., 2013; Kaspary et al., 2014a; Kaspary et al., 2014b; Cavalcante et al., 2016).

Chlorophyll meters indirectly determine the relative chlorophyll content, which is calculated by the amount of light transmitted by the leaf measured at wavelengths with variable absorbance, providing a unique reading proportional to the contents of chlorophyll $a$, chlorophyll $b$, and carotenoids (Falker Automação Agrícola, 2009; Minolta Camera Company, 1989). Models of chlorophyll meters describe the relationship between portable chlorophyll meter readings and extractable chlorophyll according to the species, their intrinsic characteristics, demanding independent calibration (Lee, 1988; Markwell et al., 1995; Uddling et al., 2007). To date, no studies have been conducted to understand the relationship between different methods of measurement of photosynthetic pigments in $A$. strigosa and $A$. sativa.

The objective of the present study was to quantify and compare the levels of photosynthetic pigments in A. strigosa and $A$. sativa using two different methods, the extraction method and portable chlorophyll meter, and to determine whether the results of these methods were significantly correlated.

\section{Results}

\section{Non-destructive method of chlorophyll measurement}

The readings of chlorophyll content obtained using the portable chlorophyll meter differed significantly with the developmental stage of $A$. strigosa and $A$. sativa $(P \leq 0.05$; Table 1). For $A$. strigosa, the chlorophyll index measured at the tillering stage was the lowest (48.83), whereas that measured at the vegetative stage I was the highest (62.42). For $A$. sativa, the mean chlorophyll index measured at the vegetative stage II was the highest (69.56), whereas that measured at the tillering stage was the lowest (47.84). For both species, the chlorophyll index measured during the reproductive stage was intermediate between those measured during other stages.

\section{Destructive method of chlorophyll measurement in the laboratory}

The evaluation of photosynthetic pigments in A. strigosa and $A$. sativa using the extraction method revealed that the contents of chlorophyll a, chlorophyll b, total chlorophyll, and carotenoids varied with the developmental stage of the plants (Table 1). For A. strigosa, the contents of chlorophyll a, chlorophyll b, total chlorophyll, and carotenoids were the lowest at the peeling stage $(1.5583,0.3334,2.7540$, and $0.4293 \mathrm{mg} \cdot \mathrm{g}^{-1} \mathrm{FLW}$, respectively) and highest at the vegetative stage I $\left(2.2922,0.4618\right.$, and $0.6828 \mathrm{mg} \cdot \mathrm{g}^{-1} \mathrm{FLW}$ chlorophyll a, chlorophyll $b$, and carotenoids, respectively) (Table 1). At the other stages, values of these pigments were intermediate, with the exception of chlorophyll a, which did not differ between the vegetative and reproductive stages. The total chlorophyll content behaved similarly to chlorophyll $\mathrm{a}$ and $\mathrm{b}$ contents measured individually.

For A. sativa, the contents of chlorophyll a, chlorophyll b, total chlorophyll, and carotenoids at vegetative stage II were

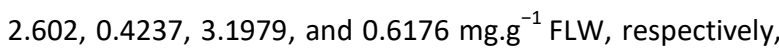
thus revealing superior photosynthetic performance at this stage (Table 1). The values of these pigments were the lowest during the cutting stage and intermediate during vegetative stage $\mathrm{I}$ and reproductive stage. These data indicate a greater accumulation of photosynthetic pigments in A. sativa than in A. strigosa.

\section{Comparison between destructive and non-destructive methods of chlorophyll measurement}

Regression analysis of the results obtained using two different methodologies (portable chlorophyll meter and laboratory extraction method) showed a high correlation, with all determination coefficients above 0.86 (Figures 1 and 2). The correlation between the chlorophyll index obtained using the chlorophyll meter and that obtained using the laboratory extraction method for chlorophyll a was high, with determination coefficients of 0.91 for both species of oats (Figure $1 \mathrm{~A}$ and $1 \mathrm{~B}$ ). For chlorophyll $\mathrm{b}$, data showed quadratic behavior and determination coefficients of 0.86 and 0.95 for $A$. strigosa and $A$. sativa, respectively (Figure $1 \mathrm{C}$ and 1D). The chlorophyll index obtained using the chlorophyll meter showed a high capacity to indirectly measure the total chlorophyll content in both oat species, with determination coefficients of 0.86 and 0.95 for $A$. strigosa and A. sativa, respectively (Figure $1 \mathrm{E}$ and $1 \mathrm{~F}$ ).

The measurement of carotenoids using the laboratory extraction method showed a strong correlation with the chlorophyll index obtained using the chlorophyll meter, with determination coefficients of 0.89 and 0.86 for A. strigosa and $A$. sativa, respectively (Figure $2 \mathrm{~A}$ and $2 \mathrm{~B}$ ). Based on the high determination coefficients, chlorophyll $a$ and $b$ contents could be correlated with the index obtained using the chlorophyll meter, and a highly reliable mathematical model was obtained for these variables when analyzed in $A$. strigosa and $A$. sativa (Figure $2 \mathrm{C}$ and $2 \mathrm{D}$ ).

\section{Discussion}

Our findings showed that the chlorophyll index increased in the vegetative stage I for $A$. strigosa and vegetative stage II for $A$. sativa with subsequent reduction in the reproductive stage (Table 1). Higher content of photosynthetic pigments facilitate the use of luminosity to the higher rate of liquid accumulation of photoassimilates, which is also linked to high growth rate (Fleck et al., 2003). This suggests that $A$. strigosa has a superior capacity to utilize luminosity in vegetative stage I, thus increasing the accumulation of dry matter and competitive potential, whereas $A$. sativa is more efficient and competitive in vegetative stage II. Thus, both oat species show different photosynthetic potential.

The results of measurement of photosynthetic pigments using the laboratory extraction method corroborated with the index obtained using the chlorophyll meter (Table 1). This trend has been reported in studies using the clorofiLOG index and laboratory extraction in Sesamum indicum, Ricinus cummunis, Lolium multiflorum, and Conyza bonariensis (Rigon et al., 2012; Rigon et al., 2014; Kaspary et al., 2014a; Kaspary et al., 2014b). 
Table 1. Relative chlorophyll index by chlorofiLOG and chlorophyll a, chlorophyll b, total chlorophyll and carotenoids (mg.g $\mathrm{g}^{-1} \mathrm{flw}$ ) by the extraction method, in A. strigosa and A. sativa. 2017.

\begin{tabular}{|c|c|c|c|c|}
\hline & Tillering & Vegetative - I & Vegetative - II & Reproductive \\
\hline $\begin{array}{l}\text { Avena strigosa } \\
\mathrm{CV}(\%)^{1}\end{array}$ & $48.83 \mathrm{~B}^{2}$ & $62.42 \mathrm{~A}$ & $51.97 \mathrm{~B}$ & $53.30 \mathrm{~B}$ \\
\hline $\begin{array}{l}\text { Avena sativa } \\
\mathrm{CV}(\%)\end{array}$ & $47.84 \mathrm{C}$ & $64.00 \mathrm{~B}$ & $\begin{array}{ll} & 69.56 \mathrm{~A} \\
5.92 & \end{array}$ & $62.00 \mathrm{BC}$ \\
\hline & Tillering & Vegetative - I & Vegetative - II & Reproductive \\
\hline $\begin{array}{l}\text { Avena strigosa } \\
\mathrm{CV}(\%)\end{array}$ & $1.5583 \mathrm{~B}$ & $2.2922 \mathrm{~A}$ & $\begin{array}{l}1, .007 \mathrm{~B} \\
t .08\end{array}$ & $1.7553 \mathrm{~B}$ \\
\hline $\begin{array}{l}\text { Avena sativa } \\
\mathrm{CV}(\%)\end{array}$ & \multicolumn{4}{|c|}{6.01} \\
\hline & Tillering & Vegetative - I & Vegetative - II & Reproductive \\
\hline $\begin{array}{l}\text { Avena strigosa } \\
\mathrm{CV}(\%)\end{array}$ & $0.3334 \mathrm{~B}$ & $0.4618 \mathrm{~A}$ & $\begin{array}{l}0.4237 \mathrm{~A} \\
3.43\end{array}$ & $0.4312 \mathrm{~A}$ \\
\hline $\begin{array}{l}\text { Avena sativa } \\
\mathrm{CV}(\%)\end{array}$ & \multicolumn{4}{|c|}{7.65} \\
\hline & Tillering & Vegetative - I & Vegetative - II & Reproductive \\
\hline $\begin{array}{l}\text { Avena strigosa } \\
\mathrm{CV}(\%)\end{array}$ & $1.8917 \mathrm{C}$ & $2.7540 \mathrm{~A}$ & $\begin{array}{l}2.0244 \mathrm{~B} \\
.32\end{array}$ & $2.1865 \mathrm{~B}$ \\
\hline $\begin{array}{l}\text { Avena sativa } \\
\text { CV }(\%)\end{array}$ & \multicolumn{4}{|c|}{8.12} \\
\hline & Tillering & Vegetative - I & Vegetative - II & Reproductive \\
\hline $\begin{array}{l}\text { Avena strigosa } \\
\text { CV }(\%)\end{array}$ & $0.4293 \mathrm{C}$ & $0.6828 \mathrm{~A}$ & $\begin{array}{l}0.6176 \mathrm{~B} \\
5.98\end{array}$ & $0.6369 \mathrm{~B}$ \\
\hline $\begin{array}{l}\text { Avena sativa } \\
\text { CV }(\%)\end{array}$ & $0.6249 \mathrm{~B}$ & $0.6993 \mathrm{~A}$ & $\begin{array}{l}0.7283 \mathrm{~A} \\
.25\end{array}$ & $0.6655 \mathrm{AB}$ \\
\hline
\end{tabular}

${ }^{1}$ Coefficient of Variation. ${ }^{2}$ Similar upper case letters in the row do not differ from one another by the DMS test at $5 \%$ significance.
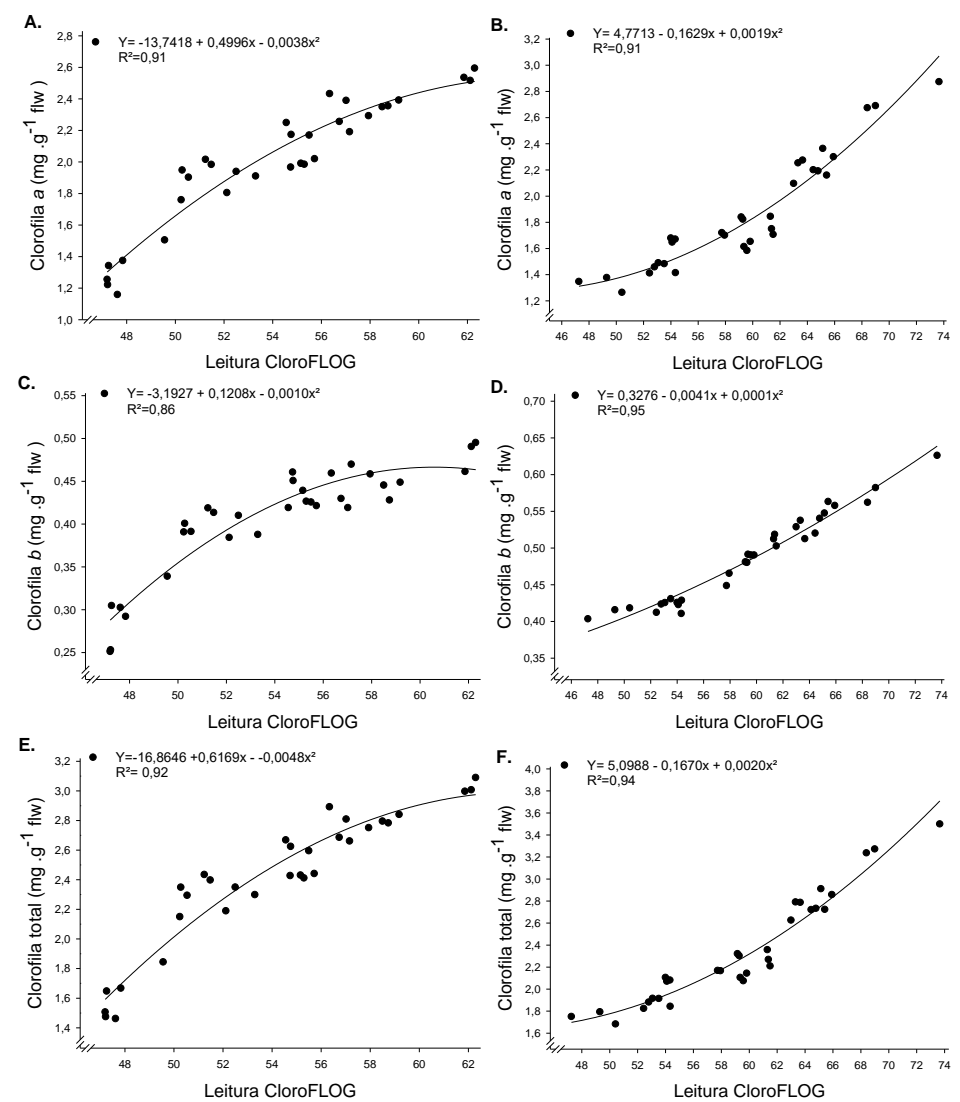

Fig 1. Relationship between the readings of the portable ClorofiLOG ${ }^{\circledR}$ for chlorophyll a, chlorophyll b, and total chlorophyll contents in A. strigosa ( $\mathrm{A}, \mathrm{C}$, and $\mathrm{E}$ ) and A. sativa (B, D, and $\mathrm{F})$. 

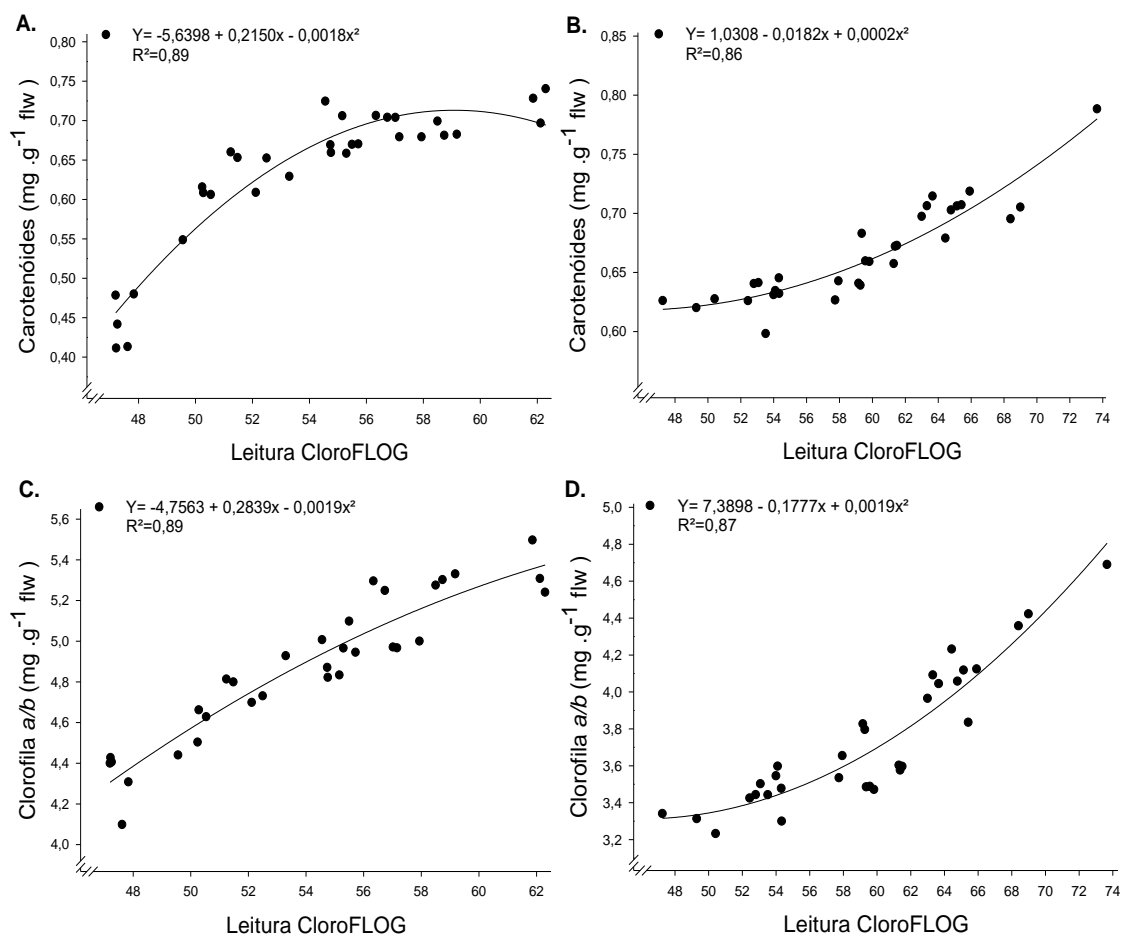

Fig 2. Relationship between the readings of the portable ClorofiLOG ${ }^{\circledR}$ for carotenoid contents and chlorophyll a/b ratio in $A$. strigosa ( $\mathrm{A}$ and $\mathrm{C}$ ) and $A$. sativa ( $\mathrm{B}$ and $\mathrm{D})$.

High correlations were observed between the two measurement methods for all analyzed photosynthetic pigments (Figures 1 and 2). Chlorophyll a, which showed a determination coefficient of 0.91 in both species of oats, also showed a high correlation in $S$. indicum and $L$. multiflorum, with determination coefficients of 0.98 and 0.96, respectively (Rigon et al., 2012, Kaspary et al., 2014). Thus, it is possible to efficiently estimate chlorophyll a content using portable chlorophyll meters and mathematical models generated in comparison to the laboratory extraction method.

High determination coefficients for chlorophyll b ( $>0.86$ for both species of oats) between the chlorophyll index measured using the chlorophyll meter and the laboratory extraction method corroborates with those observed in $C$. bonariensis ( $>0.90$ in the two evaluated biotypes) (Kaspary et al., 2014b). However, measuring chlorophyll b content using chlorophyll meters is more difficult than measuring chlorophyll a content (Neves et al., 2005) because the wavelength emitted by the apparatus is closer to the absorption peak of chlorophyll a $(660 \mathrm{~nm})$, whereas the absorption of chlorophyll b has two peaks (500 and $650 \mathrm{~nm}$ ) (Divittorio, 2009). However, in the present study, high efficiency was observed in the chlorofiLOG readings in relation to the laboratory analyses for $A$. strigosa and $A$. sativa. Similarly, as observed in the present study, high reliability coefficients were obtained for chlorophyll $b$ and clorofiLOG readings in L. multiflorum and $C$. bonariensis (Kaspary et al., 2014a; Kaspary et al., 2014b).

The total chlorophyll content also showed a high correlation with the chlorophyll index, with determination coefficients of 0.92 and 0.94 for A. strigosa and A. sativa, respectively (Figure $1 \mathrm{E}$ and $1 \mathrm{~F}$ ). These values corroborate with those obtained using the correlation method in Gossypium hirsutum and S. indicum, with coefficients of 0.91 and 0.98 , respectively (Brito et al., 2011, Rigonet al., 2012). This confirms that it is possible to adjust a mathematical model of high reliability for this variable, when comparing the measurements of pigments using different methods in $A$. strigosa and $A$. sativa (Figure $1 \mathrm{E}$ and $1 \mathrm{~F}$ ).

The relationship between chlorophyll and carotenoid contents of leaves in $A$. strigosa and A. sativa, shown in Figures $2 \mathrm{~A}$ and $2 \mathrm{~B}$, present equations of high representativeness, making it possible to estimate the actual content of these plant pigments from the readings of chlorofiLOG. Similar results have been reported for corn and cotton (Ciganda et al., 2009; Brito et al., 2011). The measurement of carotenoids is important because these pigments act as photoprotectors in photosystem II and dissipate excess light energy, thus avoiding chlorophyll damage via their high antioxidant potential (Li et al. 2010). The ratio of chlorophyll content to carotenoid content is altered under stress conditions affecting a plant, especially under water stress (Young and Britton, 1990). Thus, the rapid and accurate measurement of carotenoid content helps in making inferences about the state of the plant. Using reliable models, the carotenoid content can be determined using readings obtained from portable chlorophyll meters.

The correlation analysis between the chlorophyll index measured using clorofilOG and extracted chlorophyll $a$ and $b$ content easured using the laboratory extraction method revealed high determination coefficients of 0.89 and 0.87 in $A$. strigosa and $A$. sativa, respectively. The relationship between chlorophyll a and chlorophyll $b$ is important in assessing the plant's ability to capture light under shade (Nakazono et al., 2001). The results obtained for the two species of oats in the present study corroborate with those observed for $R$. communis, $L$. multiflorum, and $C$. bonariensis, which showed determination coefficients of 
0.70, 0.88, and 0.93, respectively (Rigon et al., 2012; Kaspary, et al., 2014a, Kaspary et al., 2014b).

The measurement of photosynthetic pigments in A. strigosa and $A$. sativa using a portable chlorophyll meter and adjusted mathematical models is accurate, efficient and economical in comparison to the laboratory extraction method. Thus, the chlorophyll meter is an important tool to determine the photosynthetic potential of oats.

\section{Materials and Methods}

\section{Plant material}

This study was conducted in a greenhouse and in the Laboratory of Chemical Analysis of the Department of Agronomic and Environmental Sciences of the Federal University of Santa Maria (UFSM), Campus of Frederico Westphalen-RS from May 2013 to October 2013. Seeds of $A$. strigosa (cultivar EMBRAPA 29) and A. sativa (cultivar URS Guapa) were sown in $6 \mathrm{~L}$ plastic pots filled with agricultural substrate. After seed germination, only one seedling was retained per pot. Photosynthetic pigments were measured using both the methods at four developmental stages, including tillering [28 days after sowing (DAS)], vegetative stage I (55 DAS), vegetative stage II (75 DAS), and reproductive stage (120 DAS). To measure photosynthetic pigments at each developmental stage, two leaves of the middle third of four plants of each oat species were analyzed and collected, totaling eight replicates per treatment.

\section{Estimation of pigment contents}

The relative chlorophyll content was measured individually using ClorofiLOG $1030^{\circ}$ portable meter, and the index reading was obtained directly from the leaf without removing it from the plant. The relative chlorophyll content determined using portable chlorophyll meters was calculated from the amount of light transmitted by the leaf based on the wavelength with variable absorbance, thus instantaneously providing a single reading proportional to the content of chlorophyll a, chlorophyll $b$, and carotenoids (Rigon et al., 2012). Portable ClorofiLOG1030 operates at the following three wavelengths: 635,660 , and $850 \mathrm{~nm}$ (Rigon et al., 2012).

\section{Measurement of chlorophyll using the destructive method}

Leaves of A. strigosa and A. sativa were collected and taken to the laboratory for analysis using the extraction methodology, as described previously (Hiscox and Israelstam, 1979). To dissolve the samples, $0.05 \mathrm{~g}$ of fresh leaf weight (FLW) was placed in test tubes containing $3 \mathrm{ml}$ of dimethyl sulfoxide (DMSO) and incubated in at $65^{\circ} \mathrm{C}$ in a water bath for $45 \mathrm{~min}$. Subsequently, $2 \mathrm{ml}$ of DMSO was added, and samples were manually shaken for $30 \mathrm{~s}$. Then, the absorbance of the final solution $(2.5 \mathrm{ml})$ containing the pigments was measured using a Biomate ${ }^{\circledR}$ tm3 spectrophotometer at 470,645 , and $663 \mathrm{~nm}$ for carotenoids, chlorophyll b, and chlorophyll a, respectively. Readings obtained at each wavelength were used in equations reported by Lichtenthaler (1987), based on the FLW, to determine the content of total chlorophyll, chlorophyll a, chlorophyll $\mathrm{b}$, and carotenoids in $\mathrm{mg} \mathrm{g}^{-1}$.

\section{Statistical analysis}

Data obtained for $A$. strigosa and A. sativa using the two methods were subjected to analysis of variance using the $F$ test, and the means of the treatments were compared using the DMS test, with a $5 \%$ probability level. The correlation between the readings obtained using the extraction method and portable chlorophyll meter was verified via regression analysis. Curve adjustments were performed by the quadratic function, according to the determination coefficient, using Sigmaplot ${ }^{\circledR}$ version 11.2.

\section{Conclusion}

Our study suggests that the measurement of photosynthetic pigments in $A$. strigosa and $A$. sativa using a portable chlorophyll meter and adjusted mathematical models is accurate and saves time and reagents in comparison to the laboratory extraction method.

\section{References}

Brito GG, Sofiatti V, Brandão ZN, Silva VB, Silva FM, Silva DA (2011) Non-destructive analysis of photosynthetic pigments in cotton plants. Acta Sci Agron. 33:671-678.

Cavalcante IHL, Silva Júnior GB, Santos EM, Lima, AMN (2016) Relationship between chlorophyll meter readings and leaf nitrogen concentration in papaya (Carica papaya L.). Philipp J Crop Sci. 41:75-79.

Ciganda V, Gitelson AA, Schepers J (2009) Nondestructive determination of maize leaf and canopy chlorophyll content. J Plant Physiol. 166:157-167.

De Castro FA, Campostrini E, Netto AT, Gomes MMA, Ferraz TM, Glenn TM (2014) Portable chlorophyll meter (PCM502) values are related to total chlorophyll concentration and photosynthetic capacity in papaya (Carica papaya L.). Theor Exp Plant Physiol. 26:201-210.

Di Vittorio AV (2009) Enhancing a leaf radiative transfer model to estimate concentrations and in-vivo specific absorption coefficients of total carotenoids and chlorophylls $a$ and $b$ from single-needle reflectance and transmittance. Remote Sens Environ. 113:1948-1966.

Engel VL, Poggiani F (1991) Estudo da concentração de clorofila nas folhas e seu espectro de absorção de luz em função do sombreamento em mudas de quatro espécies florestais nativas. Rev Bras Fis Veg. 3:39-45.

Falker (2009) Automação agrícola. Medidor eletrônico de teor de clorofila: dados técnicos clorofiLOG CFL1030. Rev. C., 6 p. http://www.falker.com.br/produto-clorofilogmedidor-clorofila.php

Fleck NG, Balbinot-Junior AA, Agostinetto D, Rizzardi MA (2003) Velocidade de estabelecimento em cultivares de arroz irrigado como característica para aumentar a habilidade competitiva com plantas concorrentes. Ci Rural. 33:635-640.

Hiscox JD, Israelstam GF (1979) A method for the extraction of chlorophyll from leaf tissue without maceration. Can J Bot. 57:1332-1334.

Kaspary TE, Lamego FP, Cutti L, Aguiar ACM, Bellé C (2014b) Determination of photosynthetic pigments in fleabane biotypes susceptible and resistant to the herbicide glyphosate. Planta Daninha. 32:417-426. 
Kaspary TE, Lamego FP, Peruzzo ST. Pagliarini IB, Rigon CAG (2014a) Pigmentos fotossintéticos em azevém suscetível e resistente ao herbicida glyphosate. Ci Rural. 44:1901-1907.

Lee DW (1988) Simulating forest shade to study the development ecology of tropical plants: Juvenile growth in three vines in India. J Trop Ecol. 4:281-292.

Li R, Shi F, Fukuda K, Yang Y (2010) Effects of salt and alkali stresses on germination, growth, photosynthesis and ion accumulation in alfalfa (Medicago sativa L.). Soil Sci Plant Nutr. 56:725-733.

Lichtenthaler HK (1987) Chlorophylls and carotenoids: pigments of photosynthetic biomembranes. In: Packer L, Douce R., ed. Methods in enzymology. - London: Academic Press, 148:350-382.

Macari S, Rocha MG, Restle J, Pilau A, Freitas FK, Neves FP (2006) Avaliação da mistura de cultivares de aveia preta (Avena strigosa Schreb) com azevém (Lolium multiflorum Lam.) sob pastejo. Ci Rural. 910-915.

Markwell J, Osterman JC, Mitchell JL (1995) Calibration of the Minolta SPAD-502 leaf chlorophyll meter. Photo Res. 46:467-472.

Minolta Camera Co. Ltd., Chlorophyll meter SPAD-502 (1989) Instruction Manual. Osaka, Minolta, p.22.

Nakazono EM, Costa MC, Futatsugi K, Silveira PMT (2001) Crescimento inicial de Euterpe edulis Mart. em diferentes regimes de luz. R Bras Bot. 24:173-179.
Neves OSC, Carvalho JG, Martins FA, Pádua TRP, Pinho PJ (2005) Uso do SPAD-502 na avaliação dos teores foliares de clorofila, nitrogênio, enxofre, ferro e manganês do algodoeiro herbáceo. Pesq Agropec Bras. 40:517-521.

Rigon JPG, Beltrão MDM, Capuani S, Brito Neto JF, Silva FVF (2012) Análise não destrutiva de pigmentos fotossintéticos em folhas de gergelim. R Bras Eng Agríc Amb. 16: 258-261.

Rigon JPG, Capuani S, Brito Neto JF, Beltrão MDM (2013) Indirect measurement of photosynthetic pigments in the leaves of Jatropha curcas. Semina: Ci Agr. 34:669-674.

Salla L, Rodrigues JC, Marenos RA (2007) Teores de clorofila em árvores tropicais determinados com SPAD-502. R Bras Bioci. 5:9-161.

Silva, LP, Ciocca MLS (2005) Total, insoluble and soluble dietary fiber values measured by enzymatic-gravimetric method in cereal grains. J. Food Compost Anal. 18:113 120.

Smeal D, Zhang H (1994) Chlorophyll meter evaluation for nitrogen management in corn. Com Soil Sci and Plan Analy. 25:1495-1503.

Uddling J, Gelang-Alfredsson J, Piikki K, Pleuel, H (2007) Evaluating the relationship between leaf chlorophyll concentration and SPAD-502 chlorophyll meter readings. I Photo Res. 91:37-46.

Young A, Britton G (1990) Carotenoids and stress. In: Alscher RG, Cummings JR. Stress responses in plants: Adaptation and acclimation mechanisms. New York: Wiley-Liss, 87112. 